UDC 621.371-537.8:621.372

I.Yu. Dmitrieva, Ph.D.

A.S. Popov Odessa National Academy of Telecommunications (ONAT), st. Kuznechmaya 1, Odessa, 65029, Ukraine.

\title{
Mathematical simulation of electromagnetic wave propagation in inhomogeneous lines
}

\begin{abstract}
Analytical study of electromagnetic wave propagation is done in the case of isotropic inhomogeneous lines in the presence of the so called expofunctional influences. Mathematical simulation is based on the corresponding boundary problems whose PDE (partial differential equation) is the general wave one regarding the unknown electromagnetic field intensities. This PDE, in its turn, is generated by the specific form of differential Maxwell system. Solvability criterion of the latter is proved in terms of equivalence to the general wave equation in the class of non generalized functions. Those boundary problems explicit solutions are suggested using classical integral transform method. Reference 20.
\end{abstract}

Keywords: mathematical simulation, electromagnetic wave propagation, inhomogeneous lines, differential Maxwell system, general wave equation.

\section{Preliminaries}

Electromagnetic field is the physical essence of signals and waves whose propagation can be described mathematically by the systems of PDEs with respect to unknown vector field intensities [17, 16]. Such systems represent analytical modeling of industrial / physical processes in the various kinds of media, and their explicit solution remains traditionally required even nowadays when computer technique develops so fast. Actually, the mentioned research area concerns almost all modern electrodynamics trends including electronics and system theory.

$$
\operatorname{rot}[\vec{H},-\vec{E}]^{T}=\left[\sigma+\varepsilon_{a} \partial_{0}^{*}, r+\mu_{a} \partial_{0}^{*}\right]^{T}[\vec{E}, \vec{H}]^{T}+\left[\vec{j}^{O S}, \vec{e}^{O S}\right]^{T}
$$

In (1): [ $]^{T}$ is the two-dimensional transposed matrix column; $\vec{E}, \vec{H}=\vec{E}(x, y, z, t), \vec{H}(x, y, z, t)$ are the unknown electromagnetic field vector intensities with scalar components $E_{k}, H_{k}=E_{k}(x, y, z, t), H_{k}(x, y, z, t)(k=\overline{1,3})$; $\sigma, \mu_{a}, \varepsilon_{a}=$ const $>0$ determine specific conductivity,
Further, in the case of systems of ODEs (ordinary differential equations) that are responsible for the simplest, even trivial, vector field modeling, an explicit solution is not of great problem. It concerns diagonalization procedure reducing initial matrix system to the equivalent union of scalar equations with respect to only one component of unknown vector field function [13]. However, as far as it is known, most naturally applied statement of the finite-dimensional system of PDEs dealing with general mathematical simulation of electromagnetic field processes and / or effects, has no proper unified analytical study even in terms of diagonalization method. It explains the main reason why suggested results concern not only exact theoretical investigation of specific electrodynamics phenomena, but tentatively show common approach of vector field problems' research basing on the operator matrices and systems of PDEs, in particular.

The given paper is generated by $[11,9,18]$ treating with reduction of differential Maxwell system to two equations in the specific case of electromagnetic field behavior. The same fact was noticed in [12] where kernels of expofunctional influences did not depend on time or turned out to be harmonic regarding the temporal argument. Basing on the experimental data of [12], it was shown there in [11] that the third and fourth differential Maxwell equations represented corollary of two other while medium was expofunctionally excited remaining homogeneous isotropic and linear. Thus the so called "symmetrical" differential Maxwell system has appeared in [10] generalizing the original system from [11]:

absolute magnetic and dielectric permeability of the medium respectively. Partial differential operators look like $\partial_{0}^{*}=\partial_{0} \pm \lambda, \partial_{0}=\partial / \partial t ; \lambda=$ const $>0$ is the signal parameter exciting the medium and sign in front of it means the reaction of medium. Absorption of signal corresponds to the " + ", and activity of the medium connects with the "-". Theoretical constant $r>0$ is responsible for the symmetry of the 
right parts in (1), and is accepted for future mathematical computation. At the last stage, $r$ can be deleted not infringing the original physical problem statement. The given functions $\vec{j}^{O S}, \vec{e}^{O S}=\vec{j}^{O S}(x, y, z, t), \vec{e}^{O S}(x, y, z, t) \quad$ whose scalar components are

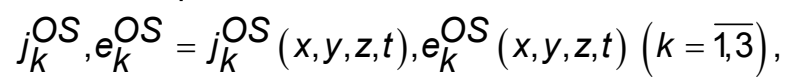
describe the outside current sources and intensities. Vectors $\vec{E}, \vec{H}, \vec{j}^{O S}, \vec{e}^{O S}$ belong to those functional classes that are required later by the particular boundary problem statement.

Analytical study of the original Maxwell system was not proposed in [11], and has appeared later in the general case of [10] using operator analogy of the algebraic Gauss method [15]. Thus (1) was reduced to the general wave equation with respect to the unknown electromagnetic vector field intensities [10]. The same result was obtained for inhomogeneous media when $\sigma, \mu_{a}, \varepsilon_{a}$ were continuous functions over the space $(x, y, z)$, and in both cases, the corresponding general wave PDE was solved explicitly [8].

Nevertheless, suggested mathematical method of operator diagonalization did not permit simulating directly specific industrial problems of technical electrodynamics. It was explained by restrictions related with matrix operator elements' invertibility [8]. This condition implied investigation of all operator kernels and their following intersection. Such approach was rather cumbersome and finally vague.

Only the inverse matrix operator construction [8] jointly with the solvability theorem has allowed formulating correctly those boundary problems analytically describing electromagnetic field features. Specific statement of (1) was considered briefly in [2], and a medium was homogeneous there. This case had to be studied separately since could not be got as the corollary of (1) [8]. More interesting inhomogeneous special statement of (1) was proposed briefly in [3] but without explicit solution of the relevant boundary problems.

Hence, the goal of the given paper is mathematical modeling of the specific electromagnetic wave propagation governed by (1) and analytical study of improved boundary problems from [3] for excited inhomogeneous case.

\section{The problem statement}

Let the specific inhomogeneous case of (1) be given

$$
\begin{aligned}
& \partial_{1}[H,-E]^{T}=\left[\sigma+\varepsilon_{a} \partial_{0}^{*}, r+\mu_{a} \partial_{0}^{*}\right]^{T} \times \\
& \times[E, H]^{T}+\left[j O S, e^{O S}\right]^{T}
\end{aligned}
$$

In (2), all designations remain the same as in (1), only instead of rot, operator $\partial_{1}=\partial / \partial x$ appears. The original vector functions from (1) are scalar here, though their physical meaning does not change, i.e.

$$
\begin{aligned}
& E, H, j^{O S}, e^{O S}= \\
& =E(x, t), H(x, t), j O S_{(x, t), e^{O S}}(x, t)
\end{aligned}
$$

Restrictions concerning these functions' belonging to the particular class are not as rigorous as earlier, and it is natural because of the simpler structure of (2) in comparison with (1). Scalar nature of electromagnetic field intensities and inhomogeneity of (2) with continuous functions $\sigma, \mu_{a}, \varepsilon_{a}=\sigma(x), \mu_{a}(x), \varepsilon_{a}(x)$ cause mathematical description of electromagnetic wave propagation in expofunctionally excited inhomogeneous lines. Besides, inhomogeneity does not influence on the further investigation procedure [2]. As it appears in [3], only solvability criterion of (2) must be considered more carefully than in the similar homogeneous case [2].

Taking into account all recent information, it should be noted that explicit study of (2) consists of three stages. The first and the second steps are shown completely in [3]. They deal with reduction of (2) to the equivalent wave PDE using the inverse matrix operator construction and solvability criterion statement. The latter is proved basing on the interrelations between (2) and the general wave equation. The last third stage concerns at first, improved formulation of boundary problems from [3] mathematically modeling electromagnetic wave propagation. Secondly, those problems proper analytical study that was not performed in [3], is done in the present paper.

\section{Main results}

Appealing to [3], the following matrix form is written for (2) 


$$
\begin{aligned}
& M F=f \\
& M=\left\{m_{i j}\right\}_{i, j=1}^{2}= \\
& =\left\{m_{11}=-m_{22}=\partial_{1} ; m_{12}=-C ; m_{21}=-D\right\} ;
\end{aligned}
$$

$C=\sigma+\varepsilon_{a} \partial_{0}^{*} ; \quad D=r+\mu_{a} \partial_{0}^{*} ; \quad F=F(x, t)=[E, H]^{T} ;$ $f=\left[j O S, e^{O S}\right]^{T}$, and the inverse operator

$$
M^{-1}=-(\operatorname{det} M)^{-1} M
$$

is found, where

$$
\operatorname{det} M=-\left(\partial_{1}^{2}+\tilde{\partial}_{0}^{2}\right)
$$

is the determinant of M. Partial differential operator $\tilde{\partial}_{0}^{2}$ from (5) looks as

$$
\tilde{\partial}_{0}^{2}=C D=\mu_{a} \varepsilon_{a}\left(\partial_{0}^{*}\right)^{2}+\left(\sigma \mu_{a}+r \varepsilon_{a}\right) \partial_{0}^{*}+\sigma r,
$$

and each "operator power" implies usual consecutive operator effect. E.g., $M^{2}$ means double application of $M$.

As it was shown in [3], influence of (4) - (6) upon (3) leads to the general scalar wave PDE regarding unknown electromagnetic field intensities

$$
\begin{gathered}
-\left(\partial_{1}^{2}+\tilde{\partial}_{0}^{2}\right) F=f^{*}, \\
f^{*}=\left[f_{1}^{*}, f_{2}^{*}\right]^{T}, f_{1}^{*}=\left[\begin{array}{ll}
-\partial_{1}, & c
\end{array}\right]^{T} f, \\
f_{2}^{*}=\left[\begin{array}{ll}
D, & \partial_{1}
\end{array}\right]^{T} f .
\end{gathered}
$$

Investigation of (5) as the square operator polynomial with respect to $\partial_{0}^{*}$ while $\mu_{a}(x), \varepsilon_{a}(x) \neq 0$, gives the real opportunity getting those conditions when inverse matrix operator $M^{-1}$ exists: either

$$
\begin{aligned}
& \partial_{1}^{2}>\left(\sigma \sqrt{\mu_{a} / \varepsilon_{a}}-r \sqrt{\varepsilon_{a} / \mu_{a}}\right)^{2} / 4, \text { or } \\
& \partial_{1}^{2} \leq\left(\sigma \sqrt{\mu_{a} / \varepsilon_{a}}-r \sqrt{\varepsilon_{a} / \mu_{a}}\right)^{2} / 4 \text { and } \\
& \partial_{0} \neq \mp \lambda- \\
& -\left(\left(\sigma / \varepsilon_{a}+r / \mu_{a}\right) \pm \sqrt{\left(\left(\sigma / \varepsilon_{a}-r / \mu_{a}\right)^{2}-4 \partial_{1}^{2} /\left(\mu_{a} \varepsilon_{a}\right)\right)}\right)
\end{aligned}
$$

If $\mu_{a}(x), \varepsilon_{a}(x)=0[7,19]$ then instead of (8), (9) such inequalities come

$$
\begin{aligned}
& \mu_{a}=0 \Rightarrow \partial_{1}^{2} \neq-r\left(\varepsilon_{a} \partial_{0}^{*}+\sigma\right), \\
& \varepsilon_{a}=0 \Rightarrow \partial_{1}^{2} \neq-\sigma\left(\mu_{a} \partial_{0}^{*}+r\right)
\end{aligned}
$$

Formulas (8) - (10) are based on the classical requirements of inverse operator $M^{-1}$ existence. It means that $\operatorname{Ker} M=\varnothing$ [14], where the left part is the kernel of original operator $M$. Numerical values in (8) - (10) are understood as acting with the corresponding class of functions, and sign reversal in front of $\lambda$ in (9) is independent of " \pm , near the square root " $\sqrt{ }$ " there.

Solvability criterion of (2) was proved completely in [3] and sounds like that: specific case (2) of the symmetrical Maxwell system (1) is solved explicitly in the meaning of its equivalence to the general scalar wave PDE (7) iff conditions (8) (10) are true. Only ordinary classical, non generalized functions are taken into account.

Comparing solvability conditions (8), (9) with those from [2], one can notice their identity. However, in the present inhomogeneous case, $\sigma(x), \mu_{a}(x), \varepsilon_{a}(x)$ are continuous functions and their numerical values can be as positive, as negative. In terms of (8), (9), the last fact implies $\operatorname{sign} \mu_{a}=\operatorname{sign} \varepsilon_{a}$, and is in conformity with the necessary condition following from the electrodynamics equations. It concerns possibility of wave propagation only in those media whose signs of magnetic and dielectric permeability are equal [7, $19,20]$. In such cases, the backward waves appear extending to the whole volume of infinite medium, and parameters of the medium become controlled owing to the magnetic field modification [20]. Besides, those media whose both electromagnetic field permeabilities are negative, form bases of the metamaterials construction $[7,19,1,5]$ whose importance of application to modern radio engineering, telecommunications, electronics and system theory is incomparable. It includes also creation of absolutely new types of waveguides, filters, antennae, etc. $[7,19,1,5]$.

The last paragraph textually almost repeats analogous information from [3, p. 149]. It was done deliberately clarifying the main tendency of current research and simplifying understanding for readers.

At last, typical boundary problems are written simulating mathematically corresponding wave propagation in inhomogeneous lines:

$$
-\left(\partial_{1}^{2}+\tilde{\partial}_{0}^{2}\right) F=f^{*}
$$




$$
\begin{aligned}
& \left\{\begin{array}{c}
x, t \in[0,+\infty): F(x, 0)=g_{1}(x),\left.F(x, t)\right|_{t \rightarrow+\infty}=0 ; \\
F(0, t)=g_{2}(t),\left.\partial_{1}^{k} F(x, t)\right|_{x \rightarrow+\infty}=0(k=0,1) .
\end{array}\right. \\
& \left\{\begin{array}{c}
x \in[0,+\infty), t \in[0, \tau]: F(x, 0)=g_{3}(x), F(x, \tau)=g_{4}(x) ; \\
F(0, t)=g_{5}(t),\left.\partial_{1}^{k} F(x, t)\right|_{x \rightarrow+\infty}=0(k=0,1) .
\end{array}\right. \\
& \left\{\begin{array}{c}
x \in[0, b], t \in[0, \tau]: F(x, 0)=g_{6}(x), F(x, \tau)=g_{7}(x) ; \\
F(0, t)=g_{8}(t), F(b, t)=g_{9}(t) .
\end{array}\right.
\end{aligned}
$$

Everywhere in (12) - (14), general wave PDE is from (11) and is determined completely in (7). The given functions $g_{l}(x)(I=1,3,4,6,7)$, $g_{i}(t)(i=2,5,8,9)$ are continuous in the respective intervals, and (11) - (14) are solved explicitly using integral transform method [6]. It is applied to the spatial variable $x$ taking temporal argument $t$ as the main one. In the cases of (11) - (13), the continuous sine Fourier transform $\int_{0}^{\infty} \sin \alpha x d x$ is used, and for (11), (14) its finite analogy $\frac{\pi}{b} \int_{0}^{b} \sin \left(\frac{\pi n}{b} x\right) \mathrm{d} x$ is expedient.

Because of the finite time interval in (13), (14) and similarity of both sine Fourier transforms' application, it seems reasonable to solve (13), (14) simultaneously, as one problem with common integral operator

$$
S=\frac{\pi}{b} \int_{0}^{d} \sin p x d x \Rightarrow\left[\begin{array}{c}
p=\alpha: d=\infty, b=\pi \\
p=\frac{\pi n}{b}: d=b
\end{array}\right.
$$

whose application to (11), (13), (14) gives

$$
\begin{gathered}
S \partial_{1}^{2} F=g^{*}-p^{2} \bar{F}, \bar{F}=\bar{F}(t)=S F \\
g^{*}=p\left[\begin{array}{c}
g_{5}(t), p=\alpha \\
(-1)^{n+1} g_{9}(t)+g_{8}(t), p=\frac{\pi n}{b}
\end{array}\right. \\
\left(\frac{\mathrm{d}^{2}}{\mathrm{~d} t^{2}}+q \frac{\mathrm{d}}{\mathrm{d} t}+c\right) \bar{F}=\bar{h} ; \\
\bar{h}=\bar{h}(t)=-\left(\bar{f}^{*}+g^{*}\right) /\left(\bar{\mu}_{a} \bar{\varepsilon}_{a}\right), \\
\bar{F}(0)=\bar{g}_{0}=\left[\begin{array}{c}
\bar{g}_{3}, p=\alpha \\
\bar{g}_{6}, p=\pi n / b
\end{array}\right. \\
\bar{F}(\tau)=\bar{g}_{\tau}=\left[\begin{array}{c}
\bar{g}_{4}, p=\alpha \\
\bar{g}_{7}, p=\pi n / b
\end{array}\right.
\end{gathered}
$$

In linear inhomogeneous ODE (17) generated by (11), constant coefficients are

$$
\begin{aligned}
& q=\bar{\sigma} / \bar{\varepsilon}_{a}+r / \bar{\mu}_{a} \pm 2 \lambda, \\
& c=\lambda^{2} \pm \lambda\left(\bar{\sigma} / \bar{\varepsilon}_{a}+r / \bar{\mu}_{a}\right)+\left(\bar{\sigma} / r-p^{2}\right) /\left(\bar{\mu}_{a} \bar{\varepsilon}_{a}\right)
\end{aligned}
$$

and everywhere, the above written "bar" determines transformed function in terms of $S$ from (15), (16). Transformed conditions (18) follow from (13), (14).

Explicit solution of common transformed boundary problem (17), (18) is looking for using the known technique [13] and following expression

$$
\bar{F}=\bar{F}_{0}+\bar{F}_{1}=\sum_{j=1}^{2}\left(C_{j 0}+C_{j 1}(t)\right) \exp \left(\omega_{j} t\right) \text {, }
$$

where: $\bar{F}_{0} / \bar{F}_{1}$ is the general / particular solution of homogeneous equation regarding (17) and inhomogeneous $\omega_{j}=\left(-q+(-1)^{j+1} \sqrt{D}\right) / 2 \quad(j=1,2)$ are the real roots of performance equation [13] $\omega^{2}+q \omega+c=0$ whose

discriminant

$D=\left(\bar{\sigma} / \bar{\varepsilon}_{a}-r / \bar{\mu}_{a}\right)^{2}+4 p^{2} /\left(\bar{\mu}_{a} \bar{\varepsilon}_{a}\right)>0$

and $\omega_{1}-\omega_{2}=\sqrt{D}$. Unknown functions $C_{j 1}(t)(j=1,2)$ are found from the differential system

$$
\sum_{j=1}^{2} C_{j 1}^{\prime}(t)\left(\exp \left(\omega_{j} t\right)\right)^{(k)}=k \bar{h}(k=0,1)
$$

and look as

$$
\begin{aligned}
& s_{j}(t)=C_{j 1}(t)= \\
& =(-1)^{j+1} /(\sqrt{D}) \int \exp \left(-\omega_{j} t\right) \bar{h} \mathrm{~d} t \\
& (j=1,2)
\end{aligned}
$$

Arbitrary real constants $C_{j 0}(j=1,2)$ are determined by the transformed initial conditions (18)

$$
\begin{gathered}
\sum_{j=1}^{2}\left(C_{j 0}+s_{j}(0)\right)=\bar{g}_{0}, \\
\sum_{j=1}^{2}\left(c_{j 0}+s_{j}(\tau)\right) \exp \left(\omega_{j} \tau\right)=\bar{g}_{\tau}
\end{gathered}
$$


and are written below

$$
\begin{array}{rlrl}
C_{j 0} & =(-1)^{j}\left(\bar{g}_{0}^{*} \exp \left(\tau \omega{ }_{(-1)}^{j+1}+j\right)-\bar{g}_{\tau}^{*}\right) /\left(\exp \left(\omega_{1} \tau\right)-\exp \left(\omega_{2} \tau\right)\right)(j=1,2), \\
\bar{g}_{0}^{*} & =\bar{g}_{0}-\sum_{j=1}^{2} s_{j}(0) & \bar{g}_{\tau}^{*}=\bar{g}_{\tau}-\sum_{j=1}^{2} s_{j}(\tau) \exp \left(\omega_{j} \tau\right) .
\end{array}
$$

Substituting (20), (21) for (19) one gets solution of (17), (18)

$\bar{F}=\sum_{j=1}^{2}(-1)^{j+1}\left(\left(\bar{g}_{\tau}^{*}-\bar{g}_{0}^{*} \exp \left(\tau \omega_{(-1)^{j+1}+j}\right)\right) /\left(\exp \left(\omega_{1} \tau\right)-\exp \left(\omega_{2} \tau\right)\right)+(\sqrt{D})^{-1} \int \exp \left(-\omega_{j} t\right) \bar{h} \mathrm{~d} t\right) \exp \left(\omega_{j} t\right)$.

Then originally unknown electromagnetic intensities F from (11), (13), (14) are got applying to (22) the inverse operator $S^{-1}$ regarding (15)

$$
S^{-1}=\frac{2}{\pi}\left[\begin{array}{l}
\int_{0}^{\infty} \sin p x \mathrm{~d} p, p=\alpha \\
0 \\
\frac{b}{\pi} \sum_{n=1}^{\infty} \sin p x, p=\pi n / b
\end{array}, F=S^{-1} \bar{F}\right.
$$

Hence, the last third step of study is done and the goal of the present article is almost attained.

\section{Conclusions}

Coming to the virtues and drawbacks of given paper it should be noted at first that the purpose is really" almost attained". It is explained by the lack of solution of (11), (12) that must be done separately because of the second initial condition from (12). As it was shown in [4], even the similar homogeneous case demands careful study, not saying about inhomogeneity that requires more accurate and thorough analysis. So, detailed explicit solution of (11), (12) is prepared for the nearest publication.

Further, though numerical implementation of (11) - (14) for particular industrial statements is not proposed yet, it is planned to be ready soon.

Turning to the suggested inverse matrix operator method, it is easy to guess that complication of matrix structure and increase of its dimension sharply exaggerates determinant study and creation of solvability conditions. Moreover, present procedure can be applied only to the inhomogeneous systems. It is quite natural because nontrivial solutions in homogeneous case are got owing to the determinant zero value that is not valid for inhomogeneity [15]. Nevertheless, in spite of lacks of the given method, the main idea and inverse matrix operator construction look useful as from theoretical, as from applied viewpoints. Future develop ment of suggested results consists of improvement on the analytical inverse matrix operator procedure for those complicated problems of technical electrodynamics whose mathematical description deals with systems of PDEs and other operator equations.

Moreover, determinant of the original matrix operator is completely responsible for its structure and inverse matrix operator existence. As the result, corresponding solvability conditions appear allowing correctly reduce the initial vector problem to the union of scalar ones. Each of the latter depends on the only one unknown functional component. Generalization of this procedure for arbitrary finite-dimensional systems of PDEs is obvious basing on the operator analogy of ordinary inverse algebraic matrix construction [15]. Suggested method together with solvability theorem allows finding correct boundary problem statement that gives, in its turn, the right mathematical modeling of respective physical or engineering process.

Considering the last modest advantages of the article, it is easy to notice that in comparison with [3] boundary problems statements are partially improved. Thus, in the second initial condition of (12), according to [4], instead of $g_{2}(x)$ from [3], the more reasonable zero value is written. In (14), particular case of $x \in[0, \pi]$ from [3] changes into $x \in[0, b], \forall b>0$.

Further, solvability criterion of (2) is general in its form meaning for homogeneous [2] and current inhomogeneous cases. Not taking into account (10), notation of (8), (9) remains the same as in [2] though $\sigma, \mu_{a}, \varepsilon_{a}$ are functions now. Moreover, this theorem proves equivalence between specific differential Maxwell system (2) and general wave PDE (7). Suggested result allows formulating required boundary problems for (2) in terms of (7). It is clear, that such approach is easier than dealing with (2) directly. 


\section{References}

1. Caloz C. Electromagnetic metamaterials: transmission line theory and microwave applications / C. Caloz, T. Itoh. - New York: Wiley \& Sons Inc., 2005. - 376 p.

2. Dmitrieva I. Specific boundary problems as an analytic investigation of signal transmissions / I. Dmitrieva // Mathematical Methods in Electromagnetic Theory (MMET 2012): the 14th IEEE Intl. Scientific Conf., 28 - 30 August 2012, Kharkiv: proceedings. - IEEEXplore: Print ISBN: 978 - 1 - 4673 - 4478 - 4, DOI: 10.1109/MMET.2012.6331179. - P. 146 - 149.

3. Dmitrieva I. Yu. Mathematical modeling of electromagnetic wave propagation in inhomogeneous medium / I. Yu. Dmitrieva // Electronics and Nanotechnology (ELNANO 2013): the 2013 IEEE XXXIII Intl. Scientific Conf., 16 - 19 April 2013, Kyiv: proceedings. - IEEEXplore: Print ISBN: $978-1-4673-4669-6$, DOI: 10.1109/ELNANO.2013.6552083. - P. 147 150.

4. Dmitrieva I. Yu. Signal propagation in semiinfinite lines and its mathematical representation / I. Yu. Dmitrieva // Odes'kyi Politechnichnyi Universitet Pratsi. - 2013. - Iss. 2(41). - P. $261-266$.

5. Marques $R$. Metamaterials with negative parameters: theory, design and microwave applications / R. Marques, F. Martin, M. Sorolla. New Jersey: Wiley \& Sons Inc., 2008. - 315 p.

6. Tranter C. J. Integral transforms in mathematical physics / C. J. Tranter. - London: Methuen and Co. Ltd., New York: John Wiley \& Sons Inc., 1951. - 119 p.

7. Вендик И. Б. Изотропный метаматериал на основе сегнетокерамических сферических включений / И. Б. Вендик, О. Г. Вендик, М. А. Одит // Физика твердого тела. - 2009. - Т. 51, вып. 8. - С. 1499 - 1503.

8. Дмитриева И. Ю. Отчет о НИР / И. Ю. Дмитриева // Одесса: ОНАС им. А. С. Попова, 2008, 2010, 2012. - Госуд. регистр. номер 0108u010946, 0109u008009, 0111U009013. - P. 10 - 25, 18 - 28, 107 115.

9. Зоммерфельд A. Электродинамика / A. Зоммерфельд; пер. с нем. под ред. С. А. Элькинда. - М.: ИЛ, 1958. - 501 с.
10. Иваницкий А. М. Диагонализация «симметричной» системы дифференциальных уравнений Максвелла / А. М. Иваницкий, И. Ю. Дмитриева // Наукові праці ОНАЗ ім. О. С. Попова. - 2007. - № 1. - С. $15-24$.

11. Иваницкий А. М. Зависимость третьего и четвертого уравнений Максвелла от первых двух уравнений при произвольном возбуждении электромагнитного поля / А. М. Иваницкий // Наукові праці ОНАЗ ім.. О. С. Попова. - 2004. - № 2. - С. 3 - 7.

12. Иваницкий A. М. Электрический заряд и магнитный поток экспофункционального поля / А. М. Иваницкий // Наукові праці ОНАЗ ім. О. С. Попова. - 2004. - № 1. - С. 3 - 8.

13. Камке Э. Справочник по обыкновенным диффференциальным уравнениям / Э. Камке; пер. с нем. С. В. Фомина. - М.: Наука, 1976. -576 c.

14. Колмогоров А. Н. Элементы теории функций и функционального анализа / А. Н. Колмогоров, С. В. Фомин. - М.: Наука, 1976. $544 \mathrm{c.}$

15. Курош А. Г. Курс высшей алгебры / А. Г. Курош. - М.: Наука, 1975. - 432 с.

16. Максвелл Дж. К. Избранные сочинения по теории электромагнитного поля / Дж. К. Максвелл; пер. с англ. 3. А. Цейтлина под ред. П. С. Кудрявцева. - М.: ГИТ-ТЛ, 1954. $687 \mathrm{c}$

17. Никольский В. В. Электродинамика и распространение радиоволн / В. В. Никольский, Т. И. Никольская. - М.: Наука, 1989. - 544 с.

18. Пименов Ю. В. Техническая электродинамика / Ю. В. Пименов, В. И. Вольман, А. Д. Муравцов. - М.: Радио и связь, 2000. - 538 с.

19. Рыженко Д. С. Применение метаматериалов при разработке волноводных СВЧ устройств: дис. ... канд. техн. наук: 05.12.07 / Рыженко Дмитрий Сергеевич. - М., 2011. $141 \mathrm{c}$.

20. Щеглов В. И. Расчет динамической проницаемости среды, содержащей магнитную и электрическую компоненты / В. И. Щеглов // Журнал радиоэлектроники. - 2001. - № 7. C. 1 - 7. - Режим доступу до журн.: http://www.jre.cplire.ru/mac/aug01/4/text.html

Поступила в редакцию 18 фревраля 2014 г. 
УДК 621.371-537.8:621.372

І.Ю. Дмитрієва, канд.фіз.-мат.наук

Одеська національна академія зв'язку ім. О.С. Попова, вул. Ковальська, 1, Одеса, 65029, Україна.

\section{Математичне моделювання поширення електромагнітних хвиль у неоднорідних лініях}

Здійснено аналітичне дослідження поширення електромагнітних хвиль у ізотропних неоднорідних лініях при наявності так званих експофуункціональних впливів. Математичне моделювання базується на відповідних крайових задачах, де чДУ (диференціальне рівняння у частинних похідних) $є$ загальним хвильовим рівнянням відносно шуканої напруженості електромагнітного поля. Дане ЧДУ, у свою чергу, породжено диференціальною системою Максвелла спеціального вигляду. Критерій розв'язання цієї системи доведено у сенсі еквівалентності загальному хвильовому рівнянню у класі неузагальнених функцій. Точний розв'язок вищезгаданих крайових задач одержано класичним методом інтегральних перетворень. Бібл. 20.

Ключові слова: математичне моделювання, поширення електромагнітних хвиль, неоднорідні лінії, диференціальна система Максвелла, загальне хвильове рівняння.

УДК 621.371-537.8:621.372

И.Ю. Дмитриева, канд.физ.-мат.наук

Одесская национальная академия связи им. А.С. Попова,

ул. Кузнечная, 1, Одесса, 65029, Украина.

\section{Математическое моделирование распространения электромаг- нитных волн в неоднородных линиях}

Осуществлено аналитическое исследование распространения электромагнитных волн в изотропных неоднородных линиях при наличии так называемых экспофункциональных воздействий. Математическое моделирование основано на соответствующих краевых задачах, где ЧДУ (дифрфреренциальное уравнение в частных производных) является общим волновым уравнением относительно искомых напряженностей электромагнитного поля. Данное чДУ, в свою очередь, порождается диффференциальной системой Максвелла специального вида. Критерий разрешимости этой системы доказан в смысле эквивалентности общему волновому уравнению в классе необобщенных фрункций. Точное решение вышеупомянутых краевых задач получено классическим методом интегральных преобразований. Библ. 20.

Ключевые слова: математическое моделирование, распространение электромагнитных волн, неоднородные линии, дифрференциальная система Максвелла, общее волновое уравнение.

\section{Список использованных источников}

1. Caloz C., Itoh T. (2005), "Electromagnetic metamaterials: transmission line theory and microwave applications". New York, Wiley \& Sons Inc. P. 376.

2. Dmitrieva I. (2012), "Specific boundary problems as an analytic investigation of signal transmissions". Proc. of the 14th International Scientific Conf. on Mathematical Methods in Electromagnetic Theory (MMET 2012), Kharkov,. IEEEXplore: Print ISBN: 978-1-4673-4478-4, DOI: 10.1109/MMET.2012.6331179, pp. 146-149.

3. Dmitrieva I.Yu. (2013), "Mathematical modeling of electromagnetic wave propagation in inhomogeneous medium". Proc. of the 2013 IEEE XXXIII International Scientific Conf. Electronics and Nanotechnology (ELNANO 2013), Kiev, IEEEXplore: Print ISBN: 978-1-4673-4669-6; DOI: 10.1109 / ELNANO.2013.6552083, pp. 147-150.

4. Dmitrieva I.Yu. (2013), "Signal propagation in semi-infinite lines and its mathematical representation". Odes'kyi Politechnichnyi Universitet Pratsi. Iss. 2(41), pp. 261-266. 
5. Marques R., Martin F., Sorolla M. (2008), "Metamaterials with negative parameters: theory, design and microwave applications". New Jersey, Wiley \& Sons Inc. P. 315.

6. Tranter C.J. (1951), "Integral transforms in mathematical physics". 1st ed., London, Methuen and Co. Ltd., New York, John Wiley \& Sons Inc. P. 119.

7. Vendik I.B., Vendik O.G., Odit M.A. (2009), "Isotropic metamaterial on the basis of segnetoceramic spherical inclusions". Phisika Tvyerdogo Tela. Vol. 51, iss. 8, pp. 1499-1503. (Rus)

8. Dmitrieva I.Yu. (2008), (2010), (2012), "Technical scientific report". Odessa, A.S. Popov ONAT, state registered no. 0108u010946, 0109u008009, , 0111U009013, pp. 10-25, 18-28, 107-115. (Rus)

9. Sommerfeld A. (1958), "Electrodynamics". Translation from German, 1st ed., Moscow, Inostrannaya Literatura. P. 501. (Rus)

10. Ivanitckiy A.M., Dmitrieva I.Yu. (2007), "Diagonalization of the "symmetrical" system of the differential Maxwell equations". A.S. Popov ONAT Naukovi Pratsi. No. 1, pp. 15-24. (Rus)

11. Ivanitckiy A.M. (2004), "Dependence of the third and fourth Maxwell equations upon the first two equations with an arbitrary excitation of the electromagnetic field". A.S. Popov ONAT Naukovi Pratsi. No. 1, pp. 3-7. (Rus)

12. Ivanitckiy A.M. (2004), "Electric charge and magnetic flux of the expofunctional field". A.S. Popov ONAT Naukovi Pratsi. No. 1, pp. 3-8. (Rus)

13. Kamke E. (1976), "Ordinary differential equations handbook". Translation from German, 5th stereotyped ed., Moscow, Nauka. P. 576. (Rus)

14. Kolmogorov A.N., Fomin S.V. (1976), "Elements of functional analysis and function theory". 4th ed., revised, Moscow, Nauka. P. 544. (Rus)

15. Kurosh A.G. (1975), "General algebra course". 11th stereotyped ed., Moscow, Nauka. P. 432. (Rus)

16. Maxwell J.C. (1954), "Selected works on the electromagnetic field theory". Translation from English, Moscow, Gosudarstvennoye Izdatelstvo Technico-Teoreticheskoi Literatury. P. 687. (Rus)

17. Nikolskiy V.V., Nikolskaya T.I. (1989), "Electrodynamics and radio wave propagation". 3rd ed., revised and supplemented, Moscow, Nauka. P. 544. (Rus)

18. Pimenov Yu.V., Volman V.I., Muravtsov A.D. (2002), "Technical electrodynamics". 3rd ed., supplemented, Moscow, Radio i svyaz. P. 536. (Rus)

19. Ryzhenko D.S. (2011), "Application of metamaterials in design of the waveguide devices with the microwave frequency". Ph.D. technics thesis 05.12.07, Moscow, N.E. Bauman Moscow State Technical Univ. P. 141. (Rus)

20. Shcheglov V.I. (2001), "Calculation of the dynamical permeability of a medium containing magnetic and electric components". Radio Electronics Journal (electronic version). No. 7, pp. 1-7. (Rus) 